\title{
IMPLEMENTASI FUZZY TIME SERIES MARKOV CHAIN MODEL (FTSMCM) DALAM PREDIKSI JUMLAH PRODUKSI AYAM POTONG
}

\author{
Desy Ika Puspitasari ${ }^{1)}$, Mochammad Arif Afianto ${ }^{2)}$ \\ ${ }^{1,2)}$ Fakultas Teknologi Informasi, UNISKA Banjarmasin \\ e-mail: smile4desyka@gmail.com ${ }^{1}$, afiantoarif78@gmail.com²)
}

\begin{abstract}
ABSTRAK
Pola konsumsi masyarakat akan produk hasil ternak semakin meningkat, tak terkecuali konsumsi ayam potong (broiler). Tingginya tingkat konsumsi masyarakat akan ayam potong otomatis akan memicu para produsen ternak untuk meningkatkan produksinya. Produksi ayam potong dapat diprediksi, salah satunya menggunakan Fuzzy Time Series. Perkembangan metode peramalan data time series yang cukup pesat mengakibatkan terdapat banyak pilihan metode yang dapat digunakan untuk meramalkan, salah satunya yaitu metode Fuzzy Time Series Markov Chain Model. Konsep Markov Chain digunakan dalam proses prediksi jumlah produksi ayam potong dengan menggunakan matriks transisi. Dengan Fuzzy Time Series Markov Chain Model, yang merupakan gabungan dari konsep metode fuzzy time series dengan model Markov, diharapkan dapat mendatangkan hasil analisis prediksi yang lebih akurat. Penelitian ini diharapkan dapat membantu proses analisis prediksi, sehingga proses analisis prediksi dapat dilakukan secara lebih efisien, teliti, mudah, dan praktis.
\end{abstract}

Kata Kunci: Ayam Potong,Markov Chain, Fuzzy Time Series,.

\begin{abstract}
The pattern of public consumption of livestock products is increasing, including the consumption of broilers. The high level of public consumption of automatic cut chicken will trigger livestock producers to increase production. Poultry production can be predicted, one of which uses Fuzzy Time Series. The development of time series data forecasting methods is quite rapid resulting in a large selection of methods that can be used to predict, one of which is the Markov Chain Model Fuzzy Time Series method. the concept of Markov Chain is used in the process of predicting the amount of production of broiled chicken using a transition matrix. With the Fuzzy Time Series Markov Chain Model, which is a combination of the concepts of fuzzy time series methods with Markov models, it is expected to bring more accurate predictive analysis results. This research is expected to be able to help the process of predictive analysis, so that the process of predictive analysis can be carried out more efficiently, meticulously, easily, and practically.
\end{abstract}

Keywords: broilers, Markov Chain, Fuzzy Time Series.

\section{PEndahuluan}

$\mathrm{D}$ Ayam potong atau ayam pedaging atau bisa disebut juga ayam boiler merupakan sumber protein hewani asal ternak dan memegang peranan yang sangat penting dilihat dari segi gizi dan ekonomi karena jenis ayam ras ini mampu tumbuh cepat sehingga dapat menghasilkan daging dalam waktu relatif singkat antara 5-7 minggu ayam sudah dapat dipanen, sehingga banyak orang tertarik pada budidaya ayam broiler [1]. Populasi ayam pedaging di Kalimantan Selatan sekitar 8,5 juta ekor dengan kontribusi produksi daging sekitar $76,79 \%$ dari total produksi daging unggas di Kalimantan Selatan [2]. Seiring dengan peningkatan jumlah permintaan ayam potong seperti yang telah dijelaskan di atas, maka diperlukan suatu aplikasi yang dapat membantu dalam proses peramalan produksi ayam potong yang dapat membantu melakukan perhitungan peramalan dengan menggunakan data jumlah produksi ayam potong dalam runtun waktu atau periode tertentu, salah satunya dengan pendekatan fuzzy time series [3].

Selain melalui pendekatan fuzzy time series, analisis prediksi suatu nilai juga dapat dilakukan dengan pendekatan Markov model. Pada penelitian Hamed Ali [4] digunakan Markov Chain untuk kegiatan prediksi dalam bidang bisnis, khususnya jumlah permintaan pada sebuah trading company. Hasil penelitian menunjukkan bahwa metode Markov Chain masih menjadi salah satu metode yang handal dalam kegiatan prediksi [5].

Penelitian ini bertujuan untuk menganalisis akurasi prediksi metode Fuzzy Time Series Markov Chain Model pada kasus jumlah produksi ayam potong di kota Banjarbaru. Sehingga hasil prediksi ini dapat digunakan sebagai bahan pertimbangan dan penentuan kebijakan oleh dinas atau instansi guna meningkatkan produksi ayam potong sesuai dengan hasil prediksi agar kebutuhan masyarakat terhadap ayam potong terpenuhi secara maksimal. 


\section{TAHAPAN PENELITIAN}

\section{A. Data Primer}

Data primer pada penelitian ini menggunakan data jumlah produksi ayam potong di kota Banjarbaru yang didapat langsung dari Dinas Pertanian, Perikanan dan Kehutanan Kota Banjarbaru.

\section{B. Desain Eksperimen}

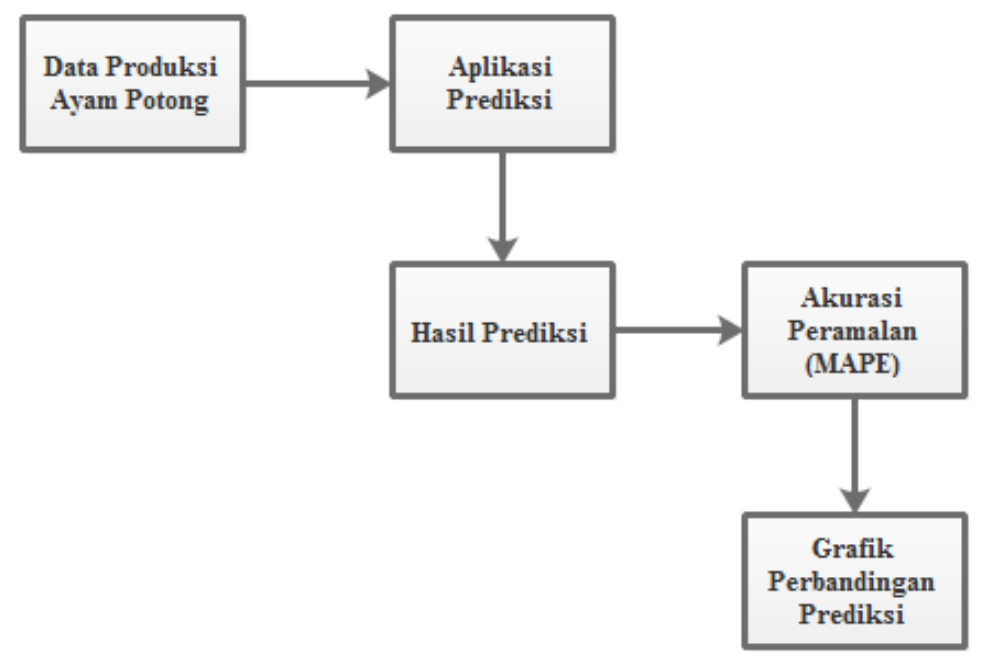

Gambar 1. Desain Eksperimen

Data produksi ayam potong, dalam bentuk file excel akan digunakan sebagai dataset dalam aplikasi prediksi, file excel tersebut akan diimport dan kemudian akan disimpan ke dalam database untuk dilakukan perhitungan. Setelah proses perhitungan selesai, maka akan ditampilkan hasil perhitungan beserta nilai akurasi peramalan, dalam hal ini perhitungan akurasi peramalan menggunakan MAPE (Mean Absolute Percentage Error). Selain itu grafik perbandingan hasil prediksi dengan data actual akan ditampilkan.

\section{Proses Pengolahan Data Awal}

Data yang ada di dalam excel akan disusun terlebih dahulu, table head diletakkan di kolom A,B dan C baris pertama sesuai urutan table head yaitu nomor, bulan produksi dan nilai produksi, sedangkan untuk data time series akan diletakkan pada baris kedua pada kolom yang sama pada table head. Hal ini bertujuan agar memudahkan aplikasi dalam mengimport file excel tersebut, dikarenakan aplikasi akan membaca satu-persatu data dimulai dari baris kedua kolom A, B dan C.

\begin{tabular}{c|c|r|r}
\hline \multicolumn{1}{c|}{ A } & \multicolumn{1}{c|}{ B } & \multicolumn{1}{c}{ C } \\
\hline 1 & No & Bular & Nilai Produksi (Ton) \\
\hline 2 & 1 & Jan-15 & 35491.03 \\
\hline 3 & 2 & Feb-15 & 34920.85 \\
\hline 4 & 3 & Mar-15 & 36159.08 \\
\hline 5 & 4 & Apr-15 & 33517.99 \\
\hline 6 & 5 & Mei-15 & 34412.69 \\
\hline 7 & 6 & Jun-15 & 39851.21 \\
\hline 8 & 7 & Jul-15 & 41217.55 \\
\hline 9 & 8 & Agu-15 & 38408.73 \\
\hline 10 & 9 & Sep-15 & 37624.82 \\
\hline 11 & 10 & Okt-15 & 40552.58 \\
\hline 12 & 11 & Nov-15 & 41427.34 \\
\hline 13 & 12 & Des-15 & 43601.33 \\
\hline 14 & 13 & Jan-16 & 42628.56 \\
\hline 15 & 14 & Feb-16 & 43502.29 \\
\hline 16 & 15 & Mar-16 & 42766.14 \\
\hline 17 & 16 & Apr-16 & 43168.69 \\
\hline 18 & 17 & Mei-16 & 41531.7 \\
\hline 19 & 18 & Jun-16 & 46954.79 \\
\hline 20 & 19 & Jul-16 & 48402.99 \\
\hline 21 & 20 & Agu-16 & 44341.07 \\
\hline 22 & 21 & Sep-16 & 42687.63 \\
\hline 23 & 22 & Okt-16 & 45188.9 \\
\hline & & & \\
\hline
\end{tabular}




\section{Parameter yang Digunakan}

Guna mengetahui pengaruh panjang interval range pada akurasi hasil prediksi serta pengaruhnya terhadap pembentukan jumlah interval, maka pada penelitian ini digunakan interval range yang berbeda diantaranya digunakan interval range 900, 700, 500 dan 300.

\section{ANALISIS DAN PERANCANGAN SISTEM}

\section{A. Flowchart Prediksi dengan Fuzzy Time Series Markov Chain Model}



Gambar III. Flowchart Prediksi dengan Fuzzy Time Series Markov Chain Model

Gambar 3 merupakan alur proses prediksi menggunakan Markov Chain Model. Data yang sudah diinput akan ditentukan data minimum dan maksimum, kemudian akan dihitung panjang intervalnya. Setelah panjang interval didapat, maka selanjutnya menentukan jumlah himpunan semesta yang akan dibentuk. Setelah $m$ jumlah himpunan semesta terbentuk, maka selanjutnya yaitu proses fuzzifikasi data, data akan ditentukan keanggotaan fuzzynya. Setelah keanggotaan fuzzy dari masing-masing data diketahui, maka selanjutnya akan dibentuk fuzzy logic relationship, dari fuzzy logic relationship ini akan dibentuk lagi fuzzy logic relationship group yaitu dengan cara mengumpulkan next state yang sama dari masing-masing current state.

Proses selanjutnya yaitu pembentukan matriks probabilitas transisi. Pada matriks probabilitas transisi ini, tiaptiap FLRG (Fuzzy Logical Relationships Group) akan dihitung nilai transisinya berdasarkan jumlah perpindahan tiap-tiap statenya. Setelah hasil nilai transisi tiap state diketahui, maka sebelum melakukan proses perhitungan prediksi, akan ditentuka terlebih dahulu apakah perpindahan dari current state ke next state hanya memiliki satu perpindahan saja ataukah lebih dari satu.

\section{B. Menghitung Hasil Peramalan}

Pada data time series, dengan menggunakan FLRG, dapat diperoleh probabilitas dari suatu state menuju ke suatu state berikutnya. Sehingga digunakan matriks transisi probabilitas markov dalam menghitung nilai peramalan, dimensi matriks transisi adalah $\mathrm{n} \times \mathrm{n}$. jika state Ai melakukan transisi menuju ke state Aj dan melewati state Ak, $i, j=1,2, \ldots, n$, maka kita dapat memperoleh FLRG. Rumus probabilitas transisi adalah sebagai berikut:

$$
P i j=\frac{M i j}{M i}, i, j=1,2, \ldots, n
$$

Dengan:

$\mathrm{P} i j=$ probabilitas transisi dari state Ai ke state Aj satu langkah 
Mij= jumlah transisi dari state Ai ke state Aj satu langkah

$\mathrm{M} i=$ jumlah data yang termasuk dalam state $\mathrm{Ai}$

\section{Akurasi Peramalan}

Tujuan dalam analisis time series adalah untuk meramalkan nilai masa depan (Wei, 2006). Metode peramalan yang bertujuan untuk menghasilkan ramalan optimum yang tidak memiliki tingkat kesalahan besar. Jika tingkat kesalahan yang dihasilkan semakin kecil, maka hasil peramalan akan semakin mendekati nilai aktual. Tingkat akurasi model peramalan yang digunakan dalam penelitian ini ialah metode uji MAPE (Mean Absolute Percentage Error) :

$$
\text { MAPE }=\frac{100 \%}{n} \sum_{t=1}^{n}\left|\frac{x t-x t^{\prime}}{x t}\right|
$$

\section{IMPLEMENTASI DAN PENGUJIAN}

\section{A. Implementasi Hasil prediksi}

1) Fuzzy Logic Relationships (FLR)

Dalam pembentukan FLR (Fuzzy Logic Relationship), kita jadikan nilai pertama hasil fuzzifikasi sebagai current value pertama dan data berikutnya sebagai next value. Dan begitu seterusnya sampai data yang terakhir, sehingga diperoleh sejumlah $n-1$ buah FLR. Seperti pada Gambar 4.

\begin{tabular}{cc} 
No & FLR \\
\hline 1 & $\mathrm{~A} 3 \rightarrow \mathrm{A} 2$ \\
\hline 2 & $\mathrm{~A} 2 \rightarrow \mathrm{A} 3$ \\
\hline 3 & $\mathrm{~A} 3 \rightarrow \mathrm{A} 1$ \\
\hline 4 & $\mathrm{~A} 1 \rightarrow \mathrm{A} 2$ \\
\hline 5 & $\mathrm{~A} 2 \rightarrow \mathrm{A} 8$ \\
\hline 6 & $\mathrm{~A} 8 \rightarrow \mathrm{A} 9$ \\
\hline 7 & $\mathrm{~A} 9 \rightarrow \mathrm{A} 6$ \\
\hline 8 & $\mathrm{~A} 6 \rightarrow \mathrm{A} 5$ \\
\hline 9 & $\mathrm{~A} 5 \rightarrow \mathrm{A} 8$ \\
\hline 10 & $\mathrm{~A} 8 \rightarrow \mathrm{A} 9$ \\
\hline 11 & $\mathrm{~A} 9 \rightarrow \mathrm{A} 12$ \\
\hline$\ldots$ & $\ldots \ldots \ldots$
\end{tabular}

Gambar IV. Fuzzy Logic Relationships (FLR)

2) Fuzzy Logic Relationships Group (FLRG)

Dalam proses peramalan FTS Markov Chain Model, ada beberapa tahap yang harus dilakukan. Adapun untuk tahap awal yang perlu dilakukan adalah mendefinisikan FLRG (fuzzy logic relationship group) yaitu dengan cara mengumpulkan tiap-tiap FLR yang terbentuk berdasarkan nilai current state yang sama. Seperti yang ditampilkan pada gambar 5 berikut ini.

\begin{tabular}{ccc} 
No & Current State & Next State \\
\hline 1 & A1 & A2 \\
\hline 2 & A2 & A3 A8 \\
\hline 3 & A3 & A1 A2 \\
\hline 4 & A5 & A8 \\
\hline 5 & A6 & A5 \\
\hline 6 & A8 & A9 A9 \\
\hline 7 & A9 & A6 A12 A15 \\
\hline 8 & A10 & A11 A11 \\
\hline 9 & A11 & A9 A10 A10 A11 A11 A12 A13 A16 \\
\hline 10 & A12 & A11 A11 \\
\hline 11 & A13 & A11 A11
\end{tabular}

Gambar 5. Fuzzy Logic Relationships Group (FLRG) 


\section{3) Matriks Probabilitas Transisi}

Matriks probabilitas yang diperoleh dari hasil perhitungan menggunakan metode FTS Markov Chain Model, dimana matriks ini merupakan komponen penting untuk menghitung hasil prediksi.

\begin{tabular}{|l|c|c|c|c|c|c|c|c|c|c|c|}
\hline & A1 & A2 & A3 & A4 & A5 & A6 & A7 & A8 & A9 & A10 & A11 \\
\hline$\square$ A1 & 0 & 1 & 0 & 0 & 0 & 0 & 0 & 0 & 0 & 0 & 0 \\
\hline$\square$ A2 & 0 & 0 & 0.5 & 0 & 0 & 0 & 0 & 0.5 & 0 & 0 & 0 \\
\hline$\square$ A3 & 0.5 & 0.5 & 0 & 0 & 0 & 0 & 0 & 0 & 0 & 0 & 0 \\
\hline$\square$ A4 & 0 & 0 & 0 & 0 & 0 & 0 & 0 & 0 & 0 & 0 & 0 \\
\hline$\square$ A5 & 0 & 0 & 0 & 0 & 0 & 0 & 0 & 1 & 0 & 0 & 0 \\
\hline$\square$ A6 & 0 & 0 & 0 & 0 & 1 & 0 & 0 & 0 & 0 & 0 & 0 \\
\hline$\square$ A7 & 0 & 0 & 0 & 0 & 0 & 0 & 0 & 0 & 0 & 0 & 0 \\
\hline$\square$ A8 & 0 & 0 & 0 & 0 & 0 & 0 & 0 & 0 & 1 & 0 & 0 \\
\hline$\square$ A9 & 0 & 0 & 0 & 0 & 0 & 0.33 & 0 & 0 & 0 & 0 & 0 \\
\hline$\square$ A10 & 0 & 0 & 0 & 0 & 0 & 0 & 0 & 0 & 0 & 0 & 1 \\
\hline$\square$ A11 & 0 & 0 & 0 & 0 & 0 & 0 & 0 & 0 & 0.13 & 0.25 & 0.25 \\
\hline
\end{tabular}

Gambar 6. Matriks Probabilitas Transisi

\section{4) Hasil Prediksi}

Hasil perhitungan ditunjukkan dalam tabel, di mana terdapat hasil perhitungan metode FTS Markov Chain Model. Di bawah tabel, juga akan muncul angka hasil perhitungan prediksi jumlah produksi ayam potong selama 1 bulan ke depan, serta nilai MAPE (Mean Absolute Percentage Error) dan MSE (Margin Square Error) yang menunjukkan tingkat akurasi dari metode FTS Markov Chain Model.

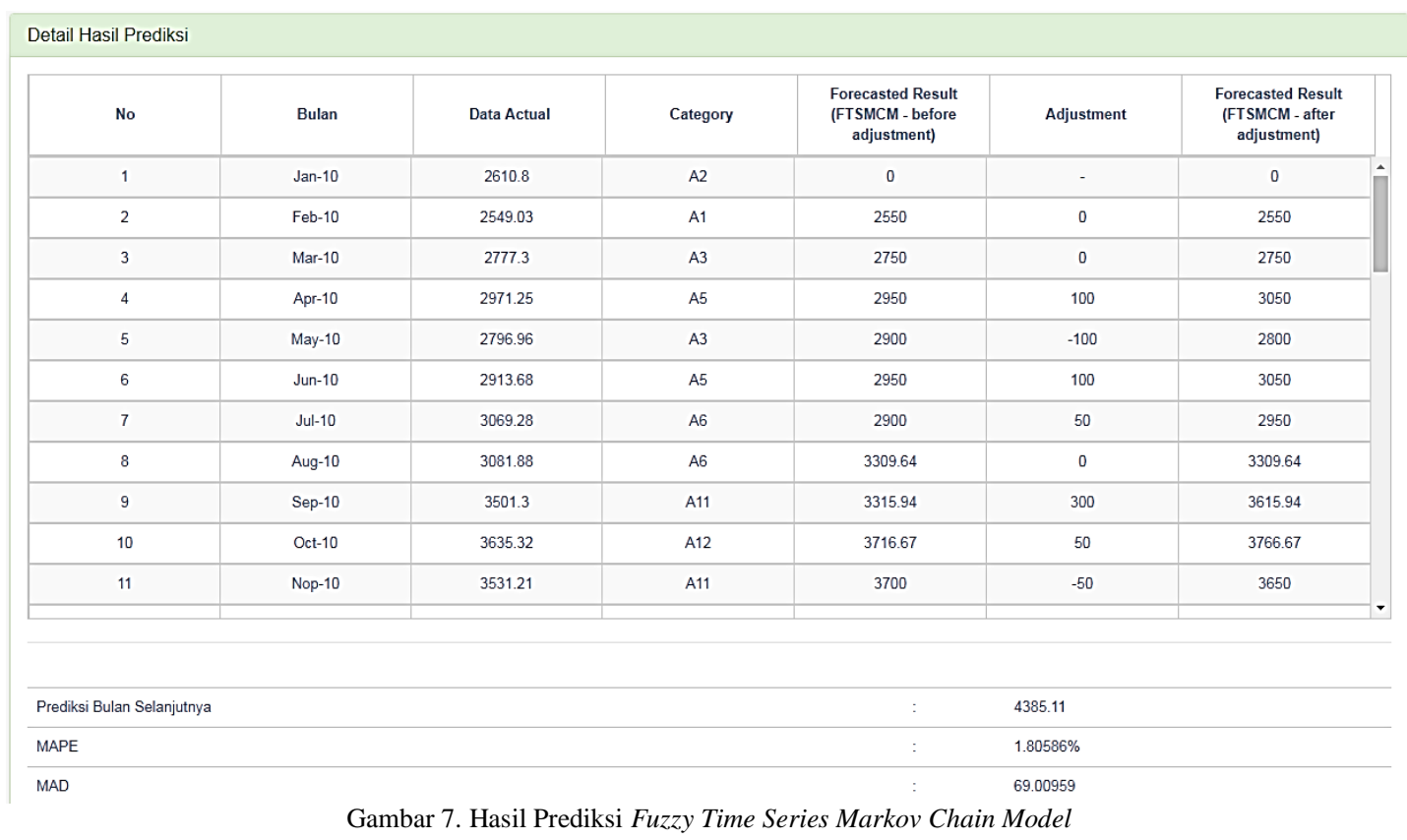

\section{B. Pengujian}

Berikut visualisasi grafik perbandingan nilai aktual dan nilai akhir prediksi dengan menggunakan metode FTSMCM untuk 30 sampel data produksi ayam potong dengan data interval range (900, 700, 500, 300). 


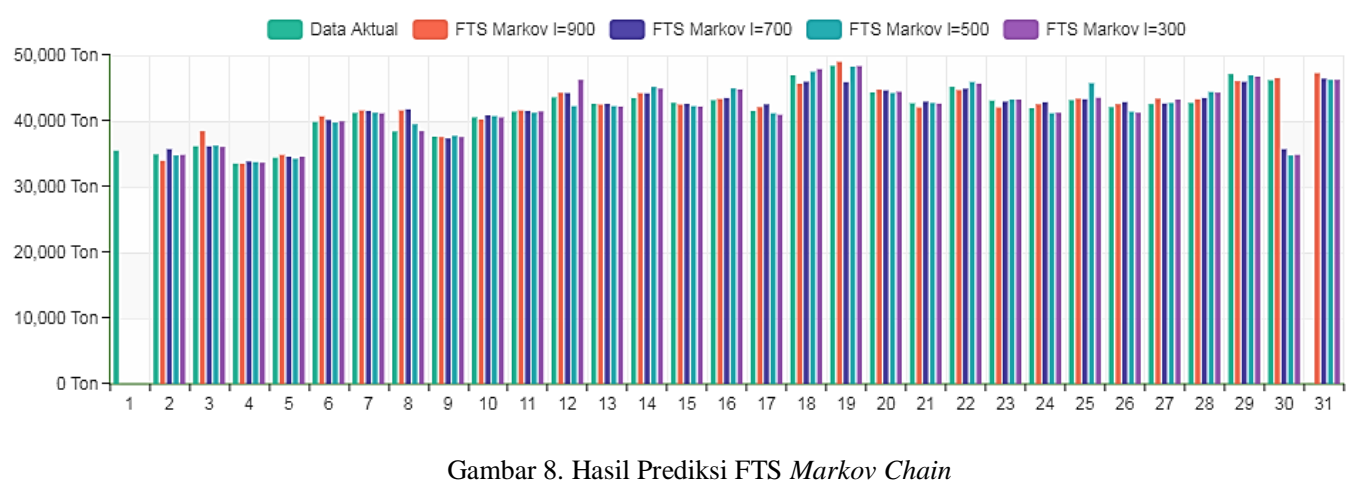

Jika ditampilkan hasil interval range pengujian MAPE dalam suatu tabel, maka hasilnya sebagai berikut :

Tabel 1. Hasil Pengujian MAPE dengan Interv
\begin{tabular}{|c|l|}
\hline Interval range $(\boldsymbol{l})$ & MAPE \\
\hline 900 & $1.67141 \%$ \\
\hline 700 & $1.48226 \%$ \\
\hline 500 & $1.32879 \%$ \\
\hline 300 & $1.15978 \%$ \\
\hline
\end{tabular}

Hasil grafik perhitungan MAPE pada tabel diatas, disajikan berikut ini :

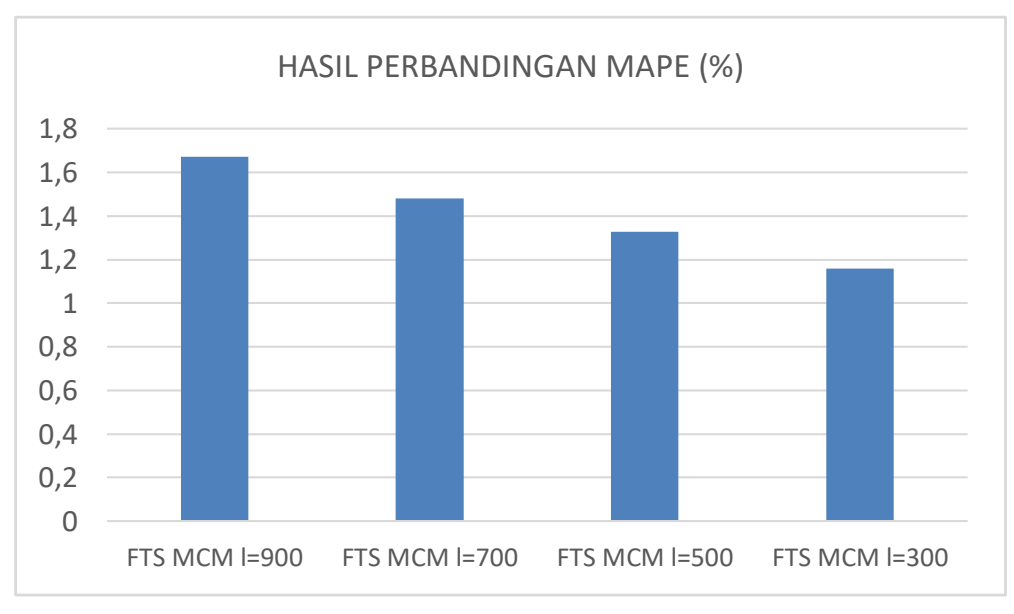

Gambar 9. Grafik Perbandingan MAPE

Pada Grafik dapat dilihat bahwa hasil pengujian MAPE yang memiliki nilai tertinggi ada pada interval range 900 yaitu 1,671. Sedangkan nilai MAPE dengan interval range 300 memiliki nilai terendah yaitu 1,159. Penggunaan interval range yang bervariasi pada metode FTS Markov Chain menunjukkan hasil MAPE yang semakin kecil semakin baik tingkat akurasinya. Dapat dilihat pada grafik semakin kecil interval range yang digunakan, maka semakin kecil pula nilai penyimpangannya.

\section{KESIMPULAN}

Metode Fuzzy Time Series Markov Chain Model berbanding lurus dengan data interval range yang digunakan. Data interval range yang kecil, akan memperkecil penyimpangan nilai prediksi yang dihasilkan. Seperti yang dapat dilihat pada hasil pengujian, interval range yang digunakan berturut-turut nilai penyimpangannya juga semakin kecil yaitu $l=900$ memiliki nilai penyimpangan $1.67141 \%, l=700$ memiliki nilai penyimpangan $1.48226 \%, l=500$ memiliki nilai penyimpangan $1.32879 \%$ dan interval range $l=300$ memiliki nilai penyimpangan $1.15978 \%$. Hal ini berarti besarnya interval range juga mempengaruhi hasil prediksi. Dilihat dari hasil perhitungan MAPE (Mean Absolute Precentage Error) Fuzzy Time Series Markov Chain Model yang memiliki nilai penyimpangan akurasi yang kecil, sehingga dapat disimpulkan bahwa hasil prediksi metode Fuzzy Time Series Markov Chain dapat menghasilkan prediksi yang cukup baik. 
JTIULM - Volume 02, Nomor 2, Bulan Desember 2017: 14 - 20

\section{DAFTAR PUSTAKA}

[1] E. Suprijatna, "Strategi Pengembangan Ayam Lokal Berbasis Sumber Daya Lokal Dan Berwawasan Lingkungan," in Seminar Nasional Unggas Lokal ke IV Fakultas Peternakan Universitas Diponegoro, no. ISBN: 978-979-097-000-7, 2010, pp. 55-88.

[2] D. P. P. K. Selatan, "Badan Pusat Statistik Provinsi Kalimantan Selatan,” 2017. [Online]. Available: https://kalsel.bps.go.id/site/resultTab. [Accessed: 08-Oct-2017].

[3] M. Ishikawa and T. Moriyama, "Prediction of time series by a structural learning of neural networks," Fuzzy Sets Syst., vol. 82, pp. 167-176, 1996.

[4] H. A. Talemi, K. Jahanbani, A. Heidarhani, A. A. Khomami, A. T. G. Sefiidi, and S. A. Abolghasemi, “Application of Markov Chain in Forecasting Demand of Trading Company," Interdiscip. J. Contemp. Res. Bus., vol. 5, no. 1, pp. 1070-1074, 2013.

[5] I. Haidar, S. Kulkarni, and H. Pan, "Forecasting Model for Crude Oil Prices Based on Artificial Neural Networks," 2008 Int. Conf. Intell. Sensors, Sens. Networks Inf. Process., pp. 103-108, 2008. 